\title{
GENDER VIOLENCE: SOCIAL REPRESENTATIONS OF RELATIVES ${ }^{1}$
}

\author{
Vanda Palmarella Rodrigues², Juliana Costa Machado ${ }^{3}$, Washington da Silva Santos ${ }^{4}$, Maria de Fátima de Souza \\ Santos ${ }^{5}$ Normélia Maria Freire Diniz ${ }^{6}$
}

\begin{abstract}
${ }^{1}$ Text from the dissertation - Social representations of relatives on gender violence, submitted to the Post-Graduation Program of the School of Nursing, Universidade Federal da Bahia (UFBA), in 2015. Scholarship from the Fundação de Amparo à Pesquisa do Estado da Bahia (FAPESB).

${ }^{2}$ Ph.D. in Nursing. Professor, Department of Health II, Universidade Estadual do Sudoeste da Bahia (UESB). Jequié, Bahia, Brazil. E-mail: vprodrigues@uesb.edu.br

${ }^{3}$ Master in Nursing and Health. Professor, Department of Health II, UESB. Jequié, Bahia, Brazil. E-mail: julicmachado@hotmail.com

${ }^{4}$ Doctoral student in Memory: Language and Society. Professor, Department of Health I, UESB. Jequié, Bahia, Brazil. E-mail: wssfisio@hotmail.com

${ }^{5}$ Ph.D. in Psychology. Professor, Universidade Federal de Pernambuco. Recife, Pernambuco, Brazil. E-mail: mfsantos@ufpe.br

${ }^{6}$ Ph.D. in Nursing. Professor, Department of Nursing, UFBA. Salvador, Bahia, Brazil. E-mail: normeliadiniz@gmail.com
\end{abstract}

\begin{abstract}
This study aimed at analyzing the social representations of gender violence by family members. A qualitative study based upon the Theory of Social Representations. The free word association test was undertaken by 81 relatives of women who suffered gender violence registered in Family Health Units of Jequié, Bahia. The data were submitted to correspondence factorial analysis in the Tri-deuxmots software. The relatives' representation of gender violence is rooted in unequal gender relations observed in the hierarchy of social relations between the man and the women, which legitimizes gender violence. Younger relatives highlighted the sexist attitudes while those aged 40 years and older highlighted the role of women as caregivers. Evangelical relatives emphasized the subordination of women while relatives who follow other religions emphasized the suffering. We emphasize the need to implement actions to address violence considering these representations in the healthcare services.
\end{abstract}

DESCRIPTORS: Violence against women. Family health. Gender and health. Nursing.

\section{VIOLÊNCIA DE GÊNERO: REPRESENTAÇÕES SOCIAIS DE FAMILIARES}

RESUMO: Analisou-se as representações sociais de familiares sobre a violência de gênero. Pesquisa qualitativa fundamentada na Teoria das Representações Sociais. Participaram do teste de associação livre de palavras 81 familiares de mulheres em situação de violência de gênero cadastrados em Unidades de Saúde da Família de Jequié, Bahia. Os dados foram submetidos à análise fatorial de correspondência no software Tri deux mots. A representação de familiares sobre a violência de gênero encontra-se ancorada nas relações desiguais de gênero, observadas na hierarquia das relações sociais estabelecidas entre a mulher e o homem, legitimando a violência de gênero. Os familiares mais jovens destacaram atitudes machistas e os de 40 anos ressaltaram o papel cuidador da mulher. As pessoas da religião evangélica enfatizaram a subalternidade da mulher e os de outras religiões, o sofrimento. Ressalta-se a necessidade de implementação de ações dos serviços de saúde no enfrentamento da violência, considerando essas representações.

DESCRITORES: Violência contra a mulher. Saúde da família. Gênero e saúde. Enfermagem.

\section{VIOLENCIA DE GÉNERO: REPRESENTACIONES SOCIALES DE LOS FAMILIARES}

\begin{abstract}
RESUMEN: Se objetivó analizar las representaciones sociales de familiares sobre la violencia de género. Investigación cualitativa fundamentada en la Teoría de las Representaciones Sociales. Participaron en el test de asociación libre de palabras 81 familiares de mujeres en situación de violencia de género inscritos en Unidades de Salud de la Familia de Jequié, Bahía. Los datos fueron sometidos a análisis factorial de correspondencia en el software Tri deux mots. La representación de familiares sobre la violencia de género se encuentra anclada en las relaciones desiguales de género, observadas en la jerarquía de las relaciones sociales establecidas entre la mujer y el hombre legitimando la violencia de género. Los familiares más jóvenes destacaron actitudes machistas y los de 40 años resaltaron el papel cuidador de la mujer. La gente de la religión evangélica enfatizó el papel subalterno de la mujer y otras religiones, el sufrimiento. Resaltamos la necesidad de implementación de acciones en los servicios de salud no enfrentamiento de la violencia, considerando esas representaciones.
\end{abstract}

DESCRIPTORES: Violencia contra la mujer. Salud de la familia. Género y salud. Enfermería. 


\section{INTRODUCTION}

Gender violence is permeated by male hegemony inherent to the relationships between men and women and by female subalternity, based on gender hierarchy. It is also marked by images that reproduce the social roles that define being a man and being a woman. ${ }^{1}$

A study performed with data from 66 countries has estimated that one in seven female homicides $(13.5 \%)$ is committed by an intimate partner. ${ }^{2}$ A review of notifications of cases of violence in Recife-PE (Pernambuco, Brazil) showed that $67.3 \%$ of the victims were females aged $20-39$ years (36.5\%), and that the main aggressor in cases of physical $(17.5 \%)$ and psychological $(27.5 \%)$ violence was the spouse. ${ }^{3}$

These data reaffirm that the power relations exerted by some men on their wives contribute to the occurrence of gender violence. The justification of biological differences for the unequal social construction for the woman and the man confirms male domination. When gender is defined as an integral element of social relations founded on the differences constructed between the sexes, it is the first means of signifying power relations. ${ }^{4-5}$

When explaining violence against women, the sociological category gender permits an approach of the diverse processes of male and female socialization, in contrast to the naturalization of their inequalities, which distance women from social emancipation. Gender violence is motivated by the expressions of inequalities between both genders that starts in family relationships. ${ }^{1,6}$

Considering a family as a concrete social group in which the social discourses and ideological constructions of the current cultural environment are transversal, studies that focus on the family must show the plane of effective social practices and the ideological and discursive constructs, with their representations and values. ${ }^{7}$

The objects of this study are the social representations of relatives of women on gender violence. The Theory of Social Representations (TSR) was the basis: it considers that all human interactions presuppose and characterize representations and influence the behavior of the participant of the collectivity as a product of actions and communications. ${ }^{8}$

We have sought to approach reality by understanding the social, cultural, historical and ideological issues that permeate this universe, and from the behavior of the relatives who live in this context.

With this study, we aim to offer a basis for the practices of healthcare professionals and for teaching, research and extension in education and health courses, so that gender violence is faced with the purpose of overcoming the socially established gender inequality.

The aim of this article was to analyze the social representations of relatives on gender violence.

\section{METHOD}

A qualitative research was performed with 81 relatives of women in situation of gender violence registered in ten Family Health Units (USF, Unidades de Saúde da Família) in the municipality of Jequié, state of Bahia. The group included mother, father, brother, sister, son, daughter, mother/ father-in-law, cousin, daughter/son-in-law and brother/sister-in-law. Data were collected from April to September 2014, using a free Word Association Test (TALP, Teste de Associação Livre de Palavras) and a semi-structured interview (81 and 19 relatives, respectively).

Data collection was only started after the research project had been approved by the Research Ethics Committee of the School of Nursing of the Universidade Federal da Bahia, with opinion no. 456.776/2013, CAEE: 23641513.8.0000.5531, and the Informed Consent Form had been signed in accordance with the Conselho Nacional de Saúde. Resolution N.466/2012.

The 81 relatives were selected by indication of the Community Health Agents (ACS, Agentes Comunitários de Saúde) of the aforementioned USF. The following inclusion criteria were considered: be a relative of the woman in situation of violence, live in the same domicile as her or in his/her own domicile, be registered in the USF, be older than 18 years, have blood kinship or not, and have the ability to maintain verbal communication.

After the TALP was performed, 19 of the 81 relatives were called to participate in the interview, considering the interest, availability and empirical data saturation, using the following prompt to start: "Tell me about your experience of domestic violence in the family".

The participant was responsible for choosing the place where the TALP would be performed. Eleven interviews were performed individually in 
the USF and 70 were performed at home. We asked the relatives to say five words for each of the following stimuli: family, being a man, being a woman, domestic violence and domestic violence against women. The fixed (sociodemographic) variables used were the following: kinship, age, religion and education.

The words were initially organized into five dictionaries for each stimulus, including all the utterances, grouped according to the frequency of repetition and semantic similarity. At a later stage, a database was built in which the social demographic characterization and each relative's utterances were recorded.

The database was submitted to the Tri Deux Mots software version 2.2 Cibois, 1995 and interpreted using the process of Correspondence Factorial Analysis (CFA). ${ }^{9}$ This program configures the analysis in a graph composed by two axes, F1 and F2, where the words with the greatest significance between the attractions and oppositions are presented.

The semi-structured interviews were performed in a comfortable and discrete place indicated by the relative. Eleven interviews were performed at the USF and eight at home, each lasting 40 minutes on average. Data from the interviews were organized using content analysis technique, thematic modality. The data were pre-analyzed and then coded and classified to establish the themes. ${ }^{10} \mathrm{We}$ then articulated the utterances originating from the CFA with the relatives' speech, using gender as a category of analysis.

To ensure participant anonymity, we numbered the family in ascending order according to interview performance, followed by the kinship with the woman in situation of violence.

\section{RESULTS AND DISCUSSION}

Of the 81 relatives, 73 were female and eight male. Among the women, 44 were aged 18-39 years and 29 were aged 40-73 years. Among the men, seven were aged 18-39 years.

Regarding female education, 32 were illiterate and/or had primary education only and 41 had secondary or higher education. Among the men, four had completed secondary school and none had higher education.

Regarding religion, 34 of the women were Evangelical, 12 believed in God but followed no religion, and two followed other religions. Among the men, four were Catholic, two Evangelical and two believed in God, but followed no religion.

Data analysis and treatment considered the responses that presented a frequency equal to or higher than four utterances for every inducing stimulus. Kinship did not influence the total percentage of responses, which seems to show a uniformity of thought among these relatives in relation to the study subject, no matter whether the family tie was in the first $(66.70 \%)$ or second $(33.30 \%)$ degree.

Being Catholic did not influence the total percentage of responses, showing a uniformity of thought by these relatives with relation to the object of the study, no matter whether the relatives stated being Catholic (35.8\%), Evangelical (44.4\%), followed other religions or believed in God but followed no religion (19.8\%).

The 81 relatives who formed the sample uttered 2024 words, and 123 different words were computed. Factor 1 (F1), represented in the horizontal line, explains $51.3 \%$ of the total response variance, with high significance.

For analysis purposes, we worked on the words uttered, shown in the two axes graph, which presents the number corresponding to the stimulus applied. The fixed variables in bold, shown in figure 1 , identify the attractions and oppositions and explore the organizing principles that form a system of representations: socially shared knowledge formed by representational elements that interrelate so that coherence and sense form a network of significance and symbols. ${ }^{11}$

In order to achieve these, we sought to articulate the utterances obtained from the stimuli, because these constitute interwoven representational elements that form a system of knowledge on gender violence which requires the incorporation of questions related to the family, such as being a man, being a woman, domestic violence and domestic violence against women. 


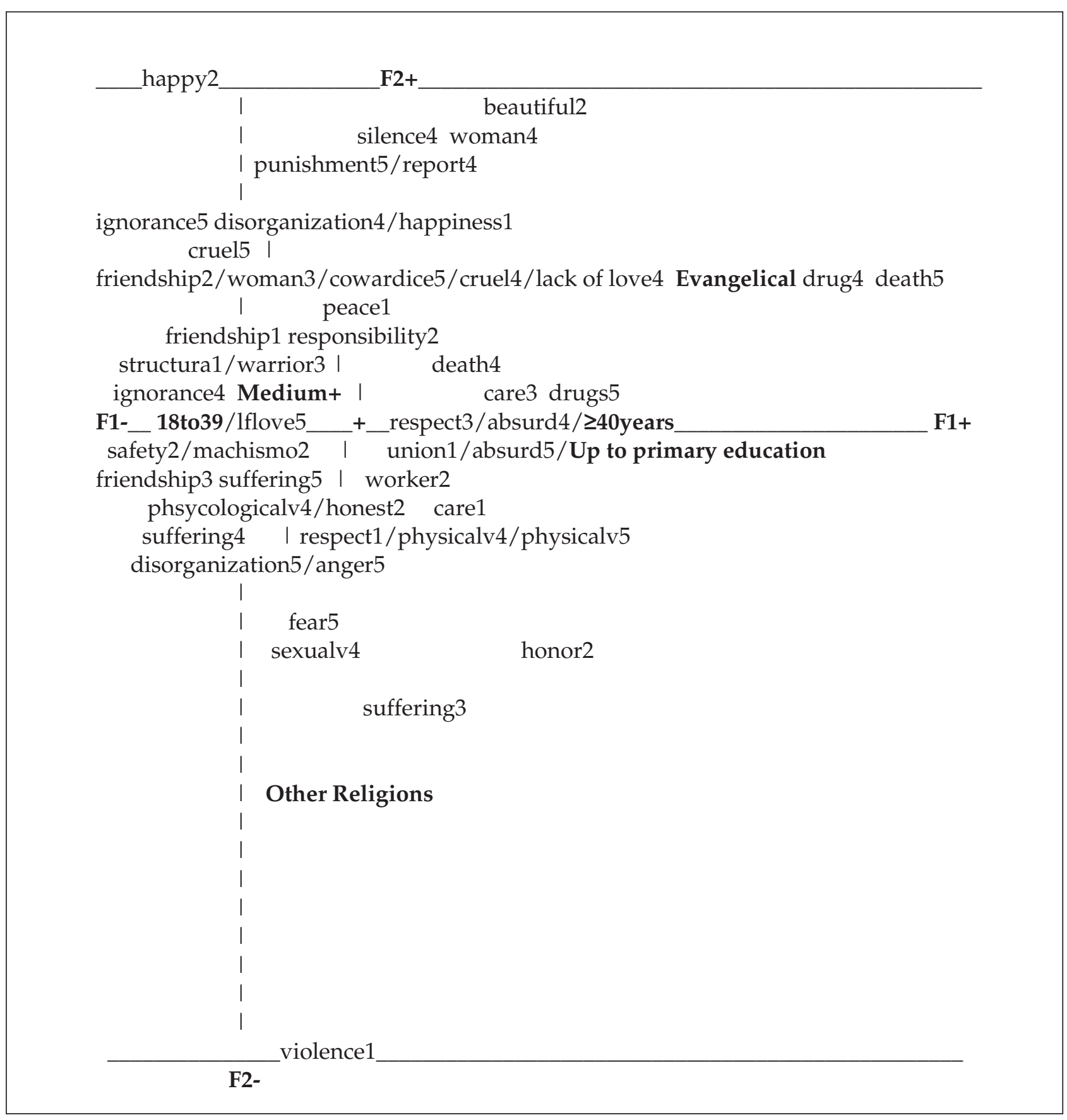

\section{Factorial plane}

Factor 1 (F1) = [horizontal axis - left (negative) and right (positive)].

Factor 2 (F2) = [vertical axis - superior (positive) and inferior (negative)].

F1(+) Relatives aged 40 years or older, illiterate or up to primary education

F1(-) Relatives aged 18-39 years, with secondary to higher education

F2(+) Relatives following Evangelical religion

F2(-) Relatives who believe in God but have no religion and follow other religions.

Fixed variables: kinship, age, religion, education.

\section{Inducing stimuli}

1 - Family

2 - Being a man

3 - Being a woman

4 - Domestic violence

5 - Domestic violence against women

Figure 1 - Correspondence factorial analysis of the social representations of relatives on domestic violence against women, Jequié-PE, Brazil, 2014 
Regarding factor 1 (F1), we observed an opposition between the relatives' age and education. The words on the right side of the graph $(\mathrm{F} 1+)$ correspond to the most frequent utterances by relatives aged 40 years or older, who are illiterate or who have completed primary education. The utterances on the left side of the ordinate axis (F1-) reflect the semantic universes mentioned by relatives aged 18-39 years with secondary and higher education.

In axis $\mathrm{F} 1+$, the relatives seem to unite organized elements around the way in which they think human family interactions should be within the context of gender violence.

In stimulus 1 (family), this group of relatives uttered the words peace, union and care. By idealizing a family with good interactions, they lead us to infer that these are representations of what should be ideal in a family and that they consider the relations of violence experienced within the home as in the following example: [...] those fights, lack of union [...] hit her, that violence (Family 19, mother).

Regarding stimulus 2 (being a man), the relative uttered the words beautiful, worker and honor. To these relatives, the value attributed to the man is related to qualities rooted in power, symbolized by beauty, work and honor According to them, the man assumes the social role of providing for the family's expenses: [...] she never worked, he was the one who worked, [he] left on Monday and came back on Friday [...] (Family 16, mother-in-law).

When the man assumes the role of providing for the family's material needs, he becomes the element of greater importance in the definition of virility. This is why they are more affected when they become unemployed and cannot care for the family nucleus. This generates a deep sense of powerlessness, which can result in violence and sexual impotence. ${ }^{12}$

The fact that these relatives uttered the word honor reinforces the principles of the culture of honor, which follows a patriarchal model. According to this model, the men must monitor the women's moral and sexual behavior. ${ }^{13}$

Regarding the third stimulus (being a woman), the words uttered were care and respect, which can indicate that violence is anchored in cultural questions. In this context, the woman would be responsible for caring or it would be necessary to show the woman respect.

The interviews reaffirmed the social role of caregivers, especially when a mother highlighted her daughter's dedication to her aggressor - she would be performing her duty and would not allow for aggressions to occur: [...] she gives him no right to be aggressive to her. She looks after the house, the children, him, she keeps the clothes clean [...] (Family 14 , mother).

When talking about fulfilling the requirements imposed on women by society, namely performing domestic chores and looking after the spouse, the interviewee exacerbated gender and power issues: this leads us to wonder whether it is possible to have rights within this context. We can consider that the representation of women is to perform the role of caregiver to the family, while the elements of the social representation of man place him in the public space, as the provider.

Relatives in this group also stated that if the woman did not perform domestic chores, her spouse had a reason to assault her. This reaffirms that the socially naturalized roles of woman and man seem to legitimize gender violence. This is clear in the following statement: [...] she would go out a lot, she would leave the children alone at home [...] [aggressor] started saying that she did not do the things at home, did not wash his clothes and argued with her, hit her [...] (Family 16, mother-in-law).

The study highlighted that, in general, violence is linked to what happens in the home, where male domination predominates. ${ }^{14}$

Regarding stimulus 4 (domestic violence), this group of relatives uttered the following terms: woman, drug, absurd and death. Drugs would precipitate violence and death would be the outcome of aggressive actions, which is considered absurd. These utterances raise reflections on the woman's cultural condition: the use of drugs represents an aggravating factor for this condition.

Domestic violence is the object of drug and death, and the woman is the victim. This content seems to be anchored in the cultural values that establish an unequal gender relation, in which the woman is the victim of violence. The drug can be an attempt to establish a cause-effect relation to violence. This would explain the violent behavior as an effect of the drug. However, the presence of a normative element that explains a negative position with relation to domestic violence was noticed. This interpretation seems to be confirmed by the subjects' utterances to the inducing stimulus "domestic violence against women".

In stimulus 5 (domestic violence against women), the following words were uttered: physical violence, absurd, drug and death. This can mean that domestic violence against women is more vis- 
ible under the form of physical violence, drug use and death.

Similar elements to the expression "domestic violence" are uttered. This seems to reinforce the idea that it is thought that domestic violence against women is caused or precipitated by drug use and victimizes the woman. Once again, there is a position that is contrary to this form of violence, which indicates the appropriation of new values by the interviewed subjects, who probably are in favor of more equal gender relations.

In this context, knowledge depends on the social and psychological context in which they are born and rooted - a way of life that makes it possible to understand the specific ways of communication and interrelationships and the formative and transformative practices of psychosocial process that ultimately form the social representations. ${ }^{15}$

In the interviews, the relatives referred to drug use as enhancers of physical violence that could lead to death.

[...] cachaça and drug, marijuana, cocaine, they use everything [three daughters] [...] they have all been raped [...] he was in prison [and] called her, [he] said he would kill her when he got out of prison, that he would break her neck [...] (Family 02, mother).

[...] she drinks cachaça and the man also drinks, the man also uses drugs, she becomes drunk and the crazy man hits her [...] (Family 06, mother).

Within this context, the abusive use of drugs would potentiate gender violence. ${ }^{16-22}$ Furthermore, the two accounts described alcohol and drug abuse by the woman and her involvement with her imprisoned companion in the context of gender violence. A study has found an association between violence by an intimate partner and alcohol use both by the man and the woman, where the woman's alcoholism increases the risk. ${ }^{20}$

When F1- is analyzed, we infer that relatives aged 18-39 years with secondary to higher education represented their experience of gender violence.

For stimulus 1 (family), these relatives uttered the words friendship and structure. We can infer that in their social imagery, the family was idealized as a structure that offered friendship among people: they were based on the traditional vision of the family as a space that should offer a structure of care for the people who are part of it.

A study of the representations of family observed that the family is understood as a space for experiences and for building relationships that provide support but produce conflicts. However, if you consider that these conflicts can be overcome, the family is conceived as the basis for everything: social relationships, human development and the health-illness process, which is the first level of healthcare. ${ }^{23}$

In general, the family is represented by feelings such as love, tenderness, happiness and union. It is idealized as the happy family shown in films, soap operas, storybooks and fairytales and values interactions based on friendship and affection between people that signify support and exchange. This can also be understood as a means of protection against suffering that reality brings on, marked by deprivation, abandonment and violence. ${ }^{23}$

These relatives uttered the words safety and machismo in response to the second stimulus (being a man). In spite of the current changes, the relatives in the study perceive the man as the person who provides safety and has machismo attitudes that reaffirm the hierarchical relationships between man and woman, especially in the context of gender violence. This fact was also observed in the interviews: [...] machismo is obvious, we live in a world in which the man thinks that he has complete control and the woman has to obey [...] be submissive, and be beaten every day, suffer violence [...] (Family 17, sister); [...] men who think that the woman is his property [...] (Family 25, cousin).

In these statements, this group of relatives expressed that the machismo attitudes are still obvious because the man feels he is in control of the situation or understands that the woman is his property. This legitimates his social position of superiority and his violent acts towards the woman, and confirms what has been observed in other studies. ${ }^{16-17,23-24}$

The third stimulus (being a woman) led the relatives to mention the words warrior and friendship. This indicates that being a warrior is a result of the woman's fight to be inserted into the public space, facing socially established hierarchies that put her in an unfavorable position in relation to man. Furthermore, while the woman is in the public space, it represents harmony in the private space.

The following words were uttered for the fourth stimulus (domestic violence): ignorance and suffering, which seem to indicate that suffering would result from ignorance, based on their daily lives and social interactions. The woman's suffering was highlighted: [...] beat her throughout the time she lived with him, beat her a lot, [it was] suffering [...] (Family 09, sister).

For stimulus 5 (domestic violence against women), the same group of relatives uttered the 
following terms: ignorance, cowardice, lack of love, suffering, disorganization and anger, highlighting the psychological suffering that originates from violent relationships. This was observed in the following report: [...] too much suffering, sadness, the woman becomes depressive, she can no longer look after her things [...] (Family 09, sister).

The psychological illness of the woman, a fact highlighted by the study, is consistent with the findings in the literature. ${ }^{17,24-25}$ A study has shown that the marks on the body of a woman in a situation of gender violence were always accompanied by great moral suffering, exacerbated by her vulnerable condition of victimization. ${ }^{24}$

When the attractions and oppositions observed in the utterances of F1+ and F1- were analyzed, we observed that the representations inherent to both groups showed an attraction for the idealization of family, anchored on the vision of family structure and friendship, even though the relatives showed evidence of violence in this space during the interviews.

The attraction observed between the representations of these two groups of relatives resulted from the elements they added when they reaffirmed that the power of men was maintained in contemporary society: the man is responsible for the safety and material provision at home.

The oppositions we found refer to the fact that the first group represented a vision in which the woman should be submissive to the man, performing domestic chores in the private space. In contrast, for the second group of relatives the woman tries to affirm her social role through her insertion in the public space.

The analysis of the vertical factor (F2) was based on religion. The upper part of the graph corresponds to the abscissa axis (F2+) and shows the utterances of the Evangelical relatives. The words in the lower part of the graph (F2-) correspond to the utterances of relatives who believe in God but follow no religion and from those who have other religions.

For factor F2+ we highlight that the Evangelical relatives presented representations that translate the context of gender violence in the public space and associate this to facing violence.

In this context, they uttered the words happiness and peace for stimulus one (family). This group of relatives also perceived that the family denotes peace and happiness, translating an idealized family interaction acceptable to society. This does not always occur, as a daughter stated when talking about her father's aggressive behavior: [...] he arrived attacking, wanting to hit [...] (Family 03, daughter).

Social representation plays important roles in maintaining the identity and social cognitive balance of a group. It mobilizes defenses against the "new" and fears it is a threat to the status quo, to the dominant values and to the thoughts that should be followed by the political and religious groups. ${ }^{26}$ Therefore, this idealization seems to have been influenced by religious thoughts, which highlight its group identity and reaffirm it belongs to this group.

Regarding stimulus 2 (being a man), the words uttered by the relatives were happiness, friendship and responsibility. This corroborates the socially accepted attitudes for the man, which are incorporated and constructed in the social imagery: a man should be happy, friendly and responsible for his family and society in general.

For the third stimulus (being a woman), the word woman was uttered, highlighting the attributes of femininity and sensitivity inherent to being a woman: in the social imagery of the study relatives, it seems clear that the insertion of women in society is related to her fragility, as observed in the following report: [...] her tooth was broken by a punch he gave her, she is so fragile, she cannot cope with him because he is strong [...] (Family 07, sister).

This study showed that the woman's fragility is exacerbated her lack of power in relation to the man and consequent subalternity, which facilitated the aggressions.

The fourth stimulus (domestic violence) the Evangelical relatives uttered the following terms: report, silence, woman, disorganization, cruel, lack of love and drug. When domestic violence is represented, they seem to show that what happened to the woman was an act of cruelty motivated by lack of love and/ or by drug use. This would lead to family disorganization, indicating the need to report it to punish the people who committed the violent acts, like criminals.

Other studies have confirmed that alcohol and drug abuse by the companion potentiates gender violence. ${ }^{16-17,22,27}$

A son's report highlighted family disorganization and teenage pregnancy due to drug use: [...] can cause damage not only to the couple, either to the woman or to the man, but to the children as well and it is a reflex of the consequences of domestic violence [...]. A family destroyed; the influence of the fighting. I would think of 
forgetting that moment and would use drugs; my sister fell pregnant [...] (Family 24, son).

This testimonial shows that violence does not affect only the man and the woman, but especially the children, who start using drugs or fall pregnant in their teenage years, disorganizing the entire family. This was confirmed by other studies. ${ }^{22,27}$

Regarding stimulus 5 (domestic violence against women), the Evangelical relatives uttered the following words: punishment, ignorance, cruel and cowardice, which leads us to infer that for these relatives domestic violence against women was a reflex of the men's ignorance, cowardice and the cruelty of their actions. The aggressor can therefore be punished by the crime he committed.

In factor F2-, we highlight that the representations of relatives who follow other religions seem to contextualize the private scope of gender violence.

In stimulus 1 (family), the words respect and violence were uttered, showing that in spite of the idea that there should be respect among people from a family, violence still occurs: [...] He hits her, curses at her [...] (Family 07, sister).

Regarding stimulus 2 (being a man), the group of relatives with other religions uttered the following words: worker and honest. This seems to denote that the man should provide for all family expenses. A representation anchored in cultural issues was also brought up, dichotomizing the social roles of the man and woman: the man works, provides for the expenses and the woman assumes her obligation towards caring.

By defining that men are the providers for the family's needs, the social representations of families in a context of vulnerability are based on cultural convictions. Women are basically restricted to the role of mothers, and not even the recent transformation society and women have undergone have been enough to change this. ${ }^{23}$

In the third stimulus (being a woman) these relatives uttered the word suffering. We inferred that it could have been expressed because of the experience of violence in the affective relationship between the woman and the man observed in their daily lives.

For the fourth stimulus (domestic violence), these relatives expressed the following terms: suffering, physical violence, psychological violence and sexual violence. We can infer that for these relatives domestic violence has reinforced the idea of suffering manifested by physical, psychological and sexual violence.
For the fifth stimulus (domestic violence against women), the relatives uttered the words physical violence, suffering, disorganization, anger and fear, signaling that a situation of physical violence leads to the woman's suffering. Feelings of anger and fear can be related to the woman's situation and to the difficulties the relatives have in dealing with the aggressor's threats and the family disorganization that results from experiencing violence.

In factor 2, the representations of the two groups showed oppositions: while the first relatives considered the family environment appropriate for peace, the other group recognized that the family constitutes the locus for the occurrence of violent acts, from what they have learned in their daily lives.

The attractions of representations from these two groups of relatives are based on gender issues: in the first group, the man was represented as incapable of committing violent acts against the woman and his role of provider was highlighted; in the second group, he was the center of family relationships due to his social role as provider.

These representations highlighted attractions when they considered the woman's fragility and her oppression and submission in affective relationships with a man, reaffirming gender issues that are very evident in these relationships.

The representations of the two groups included different positions: the Evangelical relatives presented the reasons and social iniquities translated into family disorganization. The other relatives pointed to the suffering and how the violence was expressed on a day-to-day basis.

\section{FINAL CONSIDERATIONS}

The social representations of gender violence by the study participants are formed by a representational system in which the power relations between a man and a woman are the main organizing principles of gender violence. This corroborates the findings of other studies, where the man is described as being the provider, sexist and inserted in the public space whereas the woman is described as the caregiver, fragile and subordinate.

In factor 1, the relatives translated what they think should be interaction between people within the context of violence and what was experienced as gender violence. In factor 2, on the one hand violence is reported to the public space and the attitudes accepted by society and the punishment of violent acts are idealized; on the other hand, suf- 
fering as a result of violence is contextualized in the private scope.

Overall, these representations are based on cultural issues and gender inequalities and show that power relations between man and woman in affective relationships are translated into destructive aspects because of the violence experienced. They are made real in the suffering and death of the woman and in her relatives' suffering.

Given that all types of violence are harmful to life and health, we believe that it is necessary to invest in training healthcare providers to prepare them to act taking all types of violence into consideration.

\section{REFERENCES}

1. Bandeira LM. Violência de gênero: a construção de um campo teórico e de investigação. Soc Estado. 2014 Mai-Ago; 29(2):449-69.

2. Stöckl H, Devries K, Rotstein A, Abrahams N, Campbell J, Watts C, et al. The global prevalence of intimate partner homicide: a systematic review. Lancet [Internet]. 2013 [cited 2014 Dec 05]; 382(9895):85965. Available from: http://www.thelancet.com/ journals/lancet/article/PIIS0140-6736(13)61030-2/ fulltext

3. Silva MCM, Brito AM, Araujo AL. Caracterização dos casos de violência física, psicológica, sexual e negligências notificados em Recife, Pernambuco, 2012. Epidemiol Serv Saúde. 2013 Jul-Set; 22(3):403-12.

4. Bourdieu P. A dominação masculina. $11^{\text {a }}$ Rio de Janeiro (RJ): Bertrand Brazil; 2012.

5. Scott J. Gênero: uma categoria útil para a análise histórica. Educ Realidade. 1995 Jul-Dez; 20(2):71-99.

6. Almeida LR, Silva ATMC, Machado LS. O objeto, a finalidade e os instrumentos do processo de trabalho em saúde na atenção à violência de gênero em um serviço de atenção básica. Interface. 2014 Jan-Mar; 18(48):47-59.

7. Rocha-Coutinho ML. Transmissão geracional e família na contemporaneidade. In: Barros ML, organizadora. Família e gerações. Rio de Janeiro (RJ): FGV; 2006.

8. Moscovici S. Representações sociais: investigações em psicologia social. Trad Pedrinho A Guareschi. $9^{a}$ ed. Petrópolis (RJ): Vozes; 2012.

9. Cibois P. L'analyse factorielle. Paris (FR): PUF, Collecion "Que sais-je?"; 1995.

10. Bardin L. Análise de conteúdo. São Paulo (SP): Edições 70; 2011.

11. Silva POM, Trindade ZA, Silva Junior A. As representações sociais de conjugalidade entre casais recasados. Estud Psicol. 2012 Set-Dez; 17(3):435-43.

12. Saffioti HIB. Gênero, patriarcado, violência. São Paulo (SP): Fundação Perseu Abramo; 2004.
13. Leites GT, Meneghel SN, Hirakata VN. Homicídios femininos no Rio Grande do Sul, Brazil. Rev Bras Epidemiol. 2014 Jul-Set; 17(3):642-53.

14. Silva EB, Padoin SMM, Vianna LAC. Violence against women and care practice in the perception of the health professionals. Texto Contexto Enferm [Internet]. 2015 Jan-Mar [cited 2015 Dec 18]; 24(1):229-37. Available from: http://www.scielo.br/scielo.php?script=sci arttext\&pid=S0104-07072015000100229\&lng=en\&nr $\mathrm{m}=$ iso\&tlng=en

15. JovchelovitchS. Os contextos do saber: representações, comunidade e cultura. Trad Pedrinho A Guareschi. Petrópolis (RJ): Vozes; 2008.

16. Rodrigues VP, Machado JC, Simões AV, Mendes VMMP, Paiva MS, Diniz, NMF. Prática de trabalhadora(e)s de saúde na atenção às mulheres em situação de violência de gênero. Texto Contexto Enferm. 2014 Jul-Set; 23(3):735-46.

17. Vieira LB, Cortes LF, Padoin SMM, Souza IEO, Paula CC, Terra MG. Abuso de álcool e drogas e violência contra as mulheres: denúncias de vividos. Rev Bras Enferm. 2014 Mai-Jun; 67(3):366-72.

18. Vieira LB, Padoin SMM, Oliveira IES, Paula CC. Intencionalidades de mulheres que decidem denunciar situações de violência. Acta Paul Enferm. 2012 MaiJun; 25(3):423-9.

19. Machado JC, Rodrigues VP, Vilela, ABA, Simões AV, Morais RLGL, Rocha EN. Violência intrafamiliar e as estratégias de atuação da Equipe de Saúde da Família. Saúde Soc. 2014 Jul-Set; 23(3):828-40.

20. Vieira EM, Perdona GSC, Santos MA. Fatores associados à violência física por parceiro íntimo em usuárias de serviços de saúde. Rev Saúde Pública. 2011 Ago; 45(4):730-7.

21. Silva ACLG, Coelho EBS, Njaine K. Violência conjugal: as controvérsias no relato dos parceiros íntimos em inquéritos policiais. Ciênc Saúde Coletiva. 2014 Abr; 19(4):1255-62.

22. Acosta DF, Gomes VLO, Fonseca AD, Gomes GC. Violence against women commited by intimate partners:(in)visibility of the problem. Texto Contexto Enferm [Internet]. 2015 Jan-Mar [cited 2015 Dec 18]; 24(1):121-7. Available from: http://www.scielo.br/ pdf/tce/v24n1/pt_0104-0707-tce-24-01-00121.pdf

23. Carinhanha JI, Penna LHG, Oliveira DC. Representações sociais sobre famílias em situação de vulnerabilidade: uma revisão da literatura. Rev Enferm UERJ. 2014 Jul-Ago; 22(4):565-70.

24. Oliveira PP, Viegas SMF, Santos WJ, Silveira EAA, Elias SC. Women victims of domestic violence: a phenomenological approach. Texto Contexto Enferm [Internet]. 2015 Jan-Mar [cited 2015 Dec 18]; 24(1):196203. Available from: http://www.scielo.br/pdf/tce/ v24n1/pt_0104-0707-tce-24-01-00196.pdf

25. Correia CM, Gomes NP, Couto TM, Rodrigues AD, Erdmann AL, Diniz NMF. Representations about suicide of women with history of domestic violence 
and suicide attempt. Texto Contexto Enferm. 2014 JanMar [cited 2015 Dec 18]; 23(1):118-25. Available from: http://www.scielo.br/pdf/tce/v23n1/pt_0104-0707tce-23-01-00118.pdf

26. Almeida GJ. As representações sociais, o imaginário e a construção social da realidade. In: Santos MFS,
Almeida LM, organizadores. Diálogos com a teoria das representações sociais. Recife (PE): Editora Universitária da UFPE; 2005.

27. Lettiere A, Nakano MAS, Bittar DB. Violência contra a mulher e suas implicações na saúde materno-infantil. Acta Paul Enferm. 2012 Jul-Ago; 25(4):524-9. 